\title{
磁気超解像再生層の磁区構造
}

\section{Magnetic Domain Structure in the Readout Layer of MSR Media}

\author{
金子正彦・中沖有克・小林 正* \\ ソニー(株)ホームネットワークカンパニ一，東京都品川区北品川 6-7-35 (罒141-0001) \\ *三重大学工学部, 津市上浜町 1515 (-514-8507)
}

M. Kaneko, A. Nakaoki, and T. Kobayashi*

Sony Corporation Home Network Company, 6-7-35 Kitashinagawa, Shinagawa-ku, Tokyo 141-0001

*Dept. of Physics Engng., Mie Univ., 1515 Kamihama, Tsu, Mie 514-8507

The stripe domain structure in a readout layer with a small perpendicular anisotropy in CAD media was calculated on the basis of three proposed stripe domain models. Without a magnetic field, the triangular-cross-section stripe domain appears only in the narrow range of $Q=K_{\mathrm{u}} /\left(2 \pi M_{\mathrm{s}}^{2}\right)$, but when a leakage field of $100 \mathrm{Oe}$ is applied from the memory layer, it becomes stable for a wide range of $Q$ values below a critical value. For $Q$ values above a critical value, the trapezoidal-cross-section stripe domain is stable. The distribution of the stable domain structure in the readout light spot was calculated, using the temperature profile and temperature dependence of magnetic parameters, on the basis of molecular field theory. The results show that a single domain in the perpendicular direction is stable in the spot's center for a leakage field of $100 \mathrm{Oe}$, and that triangular stripe domain area is expanded in the spot's circumference for a leakage field of $200 \mathrm{Oe}$. The result is discussed in relation to the copying process and the gray masking phenomenon.

Key words: "stripe domain, magnetic domain structure, perpendicular anisotropy, CAD, readout layer, leakage flux

\section{1.はじめに}

磁気超解像 MSR (Magnetically induced Super Resolution) メディアでは磁性多層膜によって，その機能が実現されている が，基板を通して光が入射する側の再生層には，GdFeCo が共 通して使われている。これはこの材料が, 再生のための磁気 カ一回転角が大きく，小さな垂直磁気異方性と小さな保磁力の ために情報を記録保持するメモリ一層からの，転写をさせやす いからである.

MSR の中で CAD (Center Aperture Detection) は高温での 転写特性のほかに，室温において再生層が面内磁化膜である特 性により，アパーチャーを小さく制限するマスク効果をあたせ ている ${ }^{1)}$.したがって, 低温で面内磁化膜, 高温で転写が容易な 垂直磁化膜というのが概略の設計指針であるが，その重要性に もかかわらず，小さな垂直磁気異方性をむつ膜の安定な磁区状 態の理論的な解析の報告は少ない.

本論文では静磁結合磁性 2 層膜 CAD ディアの再生層を想 定して, メモリ一層からの転写磁界も考慮して, 再生層の安定 な磁区状態をシミュレーションで求め, 光スポット内の磁区の 分布を議論した。

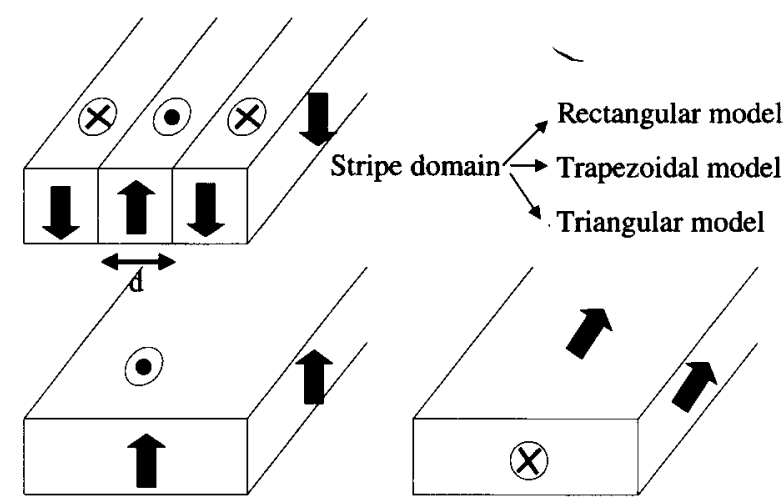

Perpendicular magnetization

Fig. 1 Possible domain states for a magnetic film with weak perpendicular magnetic anisotropy.

\section{2. 磁区構造モデル}

安定な磁区構造を求めるために，Fig. 1 に示したように，垂 直磁化状態, 面内磁化状態, ストライプ磁化状態のエネルギー を比較することが行われる2). 代表的な $\mathrm{GdFeCo}$ 再生層の磁気 パラメー夕は膜厚 $t=30 \mathrm{~nm}$, 磁化 $M_{\mathrm{s}}=100 \sim 300 \mathrm{emu} / \mathrm{cm}^{3}$, 磁気異方性 $K_{\mathrm{u}}=1 \times 10^{5} \mathrm{erg} / \mathrm{cm}^{3}$ 程度であり，規格化された磁 気異方性 $Q=K_{\mathrm{u}} /\left(2 \pi M_{\mathrm{s}}{ }^{2}\right)$ は 1 前後の值となる.このような膜 における磁区構造を分析するため, ストライプ磁区を 3 種類に 分類して以下のようにモデル化して考えることにする．共通す ることとして， $z$ 方向上向き磁区と下向き磁区が周期 $2 d$ にて 面内 $x$ 方向に繰り返されている構造を想定する. 面内 $y$ 方向と 膜厚 $z$ 方向には一様な構造とする.

\section{1 矩形波ストライプ磁区}

磁気バブルのようにQ 值の大きな材料ではストライプ磁区 構造をとることが知られている，Q》1 の極限のモデルとして, 磁壁幅はゼロとしているので, $y$ - $z$ 平面内での磁化の向きを $y$ 方向からの角度 $\theta$ で表すと, Fig. $2 \mathrm{a}$ のようになる。文献 2 に おいてはこのモデルのみが扱われている。

\section{2 台形波ストライプ磁区}

実際の再生層の $Q$ 值は 1 に近い值なので, 磁壁厚みは無視 できない，そこで磁壁厚み $\pi \delta$ 内で磁化の向きが $-\pi / 2$ から $\pi /$ 2 まで線形に変化する Fig. 2b のモデルを考えた。 


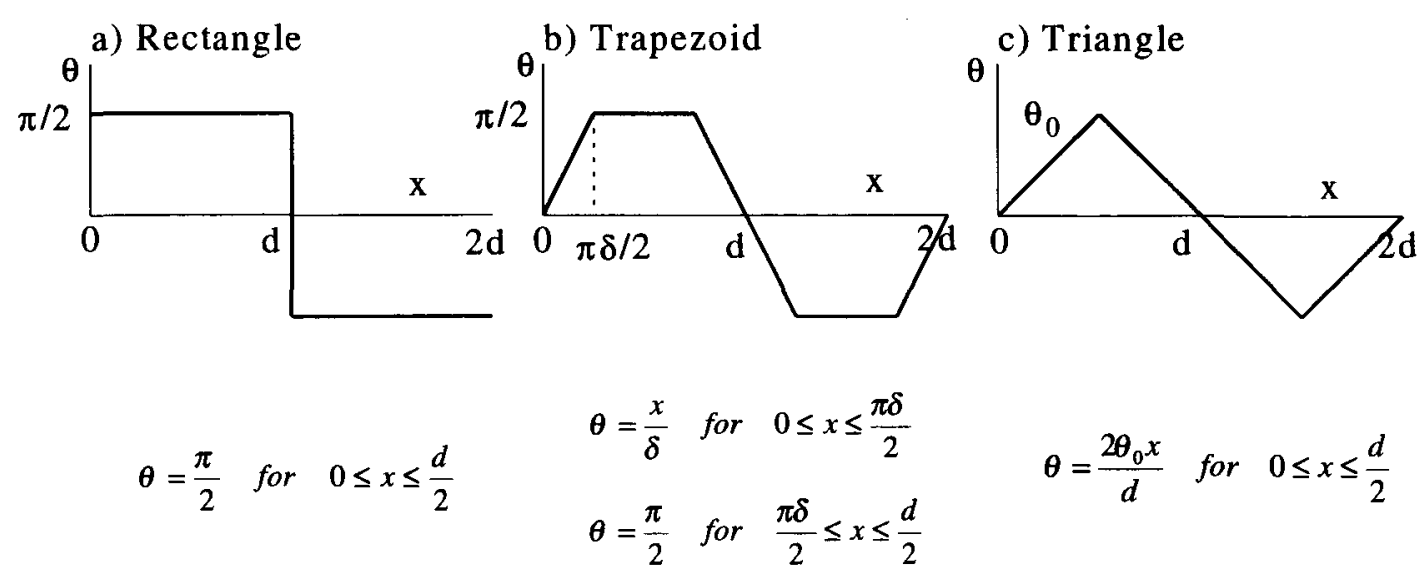

Fig. 2 Models for stripe domains with relatively small anisotropy energy.

\section{3 三角波ストライプ磁区}

$Q$ 值が 1 より小さい極薄膜では, 磁壁厚みがストライプ幅 $d$ と同等になった結果として，Fig. 2c のような構造をとりうる ことが, 垂直異方性のあるパーマロイ膜で, 実験的, 理論的に 検証されている3!， $\theta$ は $x$ に対して，最大值 $\theta_{0}$ まで線形に変化 する。

\section{3. 磁区のエネルギー}

単位体積当たりの磁区のエネルギーは，周期 $2 d$ にわたる平 均値が，対称性から $0<x<(d / 2)$ での平均で与えられることか ら以下のようになる.

磁気異友性エネルギー：

$$
E_{\mathrm{a}}=\frac{2}{d} \int_{0}^{d / 2} K_{\mathrm{u}} \cos ^{2} \theta \mathrm{d} x
$$

$$
\begin{aligned}
& \text { 交換エネルギー: } \\
& \qquad E_{\mathrm{ex}}=\frac{2}{d} \int_{0}^{d / 2} A\left(\frac{\mathrm{d} \theta}{\mathrm{d} x}\right)^{2} \mathrm{~d} x
\end{aligned}
$$

\section{ここで $A$ は交換エネルギー定数である.}

静磁エネルギー：

Fig. 2 加ら与えられる膜厚 $t$ の上面 $z=0$, 下面 $z=-t$ におけ る磁荷によるスカラーポテンシャルをそれぞれ $\phi_{1}, \phi_{2}$ よするよ 周期性より

$$
\begin{aligned}
& \phi_{1}=\sum_{n} A_{n} \sin \frac{n \pi x}{d} \exp \left(\frac{n \pi z}{d}\right) \\
& \phi_{2}=\sum_{n} B_{n} \sin \frac{n \pi x}{d} \exp \left(-\frac{n \pi(z+t)}{d}\right)
\end{aligned}
$$

と記述できる、境界条件は

$$
\begin{aligned}
& \left(\frac{\partial \phi_{1}}{\partial z}\right)_{z=-0}=2 \pi M_{\mathrm{s}} \sin \theta \\
& \left(\frac{\partial \phi_{2}}{\partial z}\right)_{z=-t+0}=-2 \pi M_{\mathrm{s}} \sin \theta
\end{aligned}
$$

で与えられる4うので, 係数は奇数項だけが残り,

$$
A_{2 n-1}=-B_{2 n-1}=\frac{8 M_{\mathrm{s}}}{(2 n-1)} \int_{0}^{d / 2} \sin \theta \sin \left(\frac{(2 n-1) \pi x}{d}\right) \mathrm{d} x
$$

と求められる。静磁エネルギーは

$$
\begin{aligned}
E_{\mathrm{s}}= & \frac{1}{2 t} \frac{2}{d} \int_{0}^{d / 2}\left[M_{\mathrm{s}} \sin \theta\left(\phi_{1}+\phi_{2}\right)_{z=0}\right. \\
& \left.-M_{\mathrm{s}} \sin \theta\left(\phi_{1}+\phi_{2}\right)_{z=-t}\right] \mathrm{d} x \\
= & \sum_{n=1}^{\infty} \frac{8\left(2 \pi M_{\mathrm{s}}{ }^{2}\right)}{t d(2 n-1) \pi}\left[\int_{0}^{d / 2} \sin \theta \sin \left(\frac{(2 n-1) \pi x}{d}\right) \mathrm{d} x\right]^{2} \\
& \times\left(1-\exp \left(-\frac{(2 n-1) \pi t}{d}\right)\right)
\end{aligned}
$$

と表される.

転写磁界との相互作用エネルギー：

静磁結合夕イプの CAD では Fig. 3 のように, 再生層には非 磁性層を介して，磁区長 $d_{\mathrm{m}}$ のメモリ一層から周期 $2 d_{\mathrm{m}}$ の転写 磁界か印加される. Fig. 3 は転写磁界により, 再生層が $d=d_{\mathrm{m}}$ とそろった場合を示している. 磁界は振幅 $H_{l}$ の矩形波で近似 すると, 転写磁界との相互作用エネルギーは以下のように表さ れる.

$$
E_{l} \frac{2}{d} \int_{0}^{d / 2}\left(-M_{\mathrm{s}} H_{l} \sin \theta\right) \mathrm{d} x
$$

$d \neq d_{\mathrm{m}}$ の場合は平均として転写磁界との相互作用エネル ギーはゼロとなる.

それぞれのモデルについて, 各エネルギーは以下のように表 わされる.

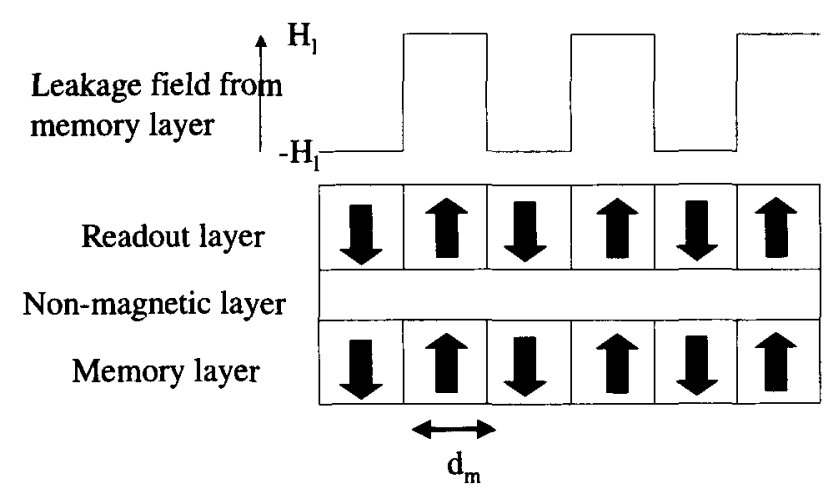

Fig. 3 Leakage field from the memory layer to the readout layer. 
垂直磁化単磁区状態

$$
E_{\mathrm{s}}=2 \pi M_{\mathrm{s}}^{2} \text { その他はゼロ }
$$

\section{面内磁化単磁区状態}

$$
E_{\mathrm{a}}=K_{\mathrm{u}} \text { その他はゼロ }
$$

矩形波ストライプ磁区

$$
\begin{aligned}
& E_{\mathrm{a}}+E_{\mathrm{ex}}=\frac{4 \sqrt{A K_{\mathrm{u}}}}{d} \\
& E_{\mathrm{s}}=\sum_{n=1}^{\infty} \frac{8\left(2 \pi M_{\mathrm{s}}^{2}\right) d}{t(2 n-1)^{3} \pi^{3}}\left(1-\exp \left(-\frac{(2 n-1) \pi t}{d}\right)\right) \\
& E_{l}=-M_{\mathrm{s}} H_{l}
\end{aligned}
$$

台形波ストライプ磁区

$$
\begin{aligned}
E_{\mathrm{a}}= & \frac{K_{\mathrm{u}} \pi \delta}{2 d} \\
E_{\mathrm{ex}}= & \frac{A \pi}{d \delta} \\
E_{\mathrm{s}}= & \sum_{n=1}^{\infty} \frac{8\left(2 \pi M_{\mathrm{s}}^{2}\right) d}{t(2 n-1)^{3} \pi^{3}} \\
& \times\left[\left(\frac{d^{2}}{\left(d^{2}-\delta^{2}(2 n-1)^{2} \pi^{2}\right)}\right) \cos \left(\frac{(2 n-1) \pi^{2} \delta}{2 d}\right)\right]^{2} \\
& \times\left(1-\exp \left(-\frac{(2 n-1) \pi t}{d}\right)\right) \\
E_{l}= & -M_{\mathrm{s}} H_{l}\left(1-\frac{(\pi-2) \delta}{d}\right)
\end{aligned}
$$

三角波ストライプ磁区

$$
\begin{aligned}
E_{\mathrm{a}}= & \frac{K_{\mathrm{u}}}{2}\left(1+\frac{\sin 2 \theta_{0}}{2 \theta_{0}}\right) \\
E_{\mathrm{ex}}= & A\left(\frac{2 \theta_{0}}{d}\right)^{2} \\
E_{\mathrm{s}}= & \sum_{n=1}^{\infty} \frac{2 d\left(2 \pi M_{\mathrm{s}}^{2}\right) \theta_{0}^{2} \cos ^{2} \theta_{0}}{t(2 n-1) \pi\left\{\left(n-\frac{1}{2}\right)^{2} \pi^{2}-\theta_{0}^{2}\right\}^{2}} \\
& \times\left(1-\exp \left(-\frac{(2 n-1) \pi t}{d}\right)\right) \\
E_{l}= & -M_{\mathrm{s}} H_{l}\left(\frac{1-\cos \theta_{0}}{\theta_{0}}\right)
\end{aligned}
$$

\section{4. 計算結果}

室温を想定して $A=3 \times 10^{-7} \mathrm{erg} / \mathrm{cm}, M_{\mathrm{s}}=150 \mathrm{emu} / \mathrm{cm}^{3}$ を 固定し，Q值と膜厚 $t$ を変えて安定な磁区を求めた。

$$
E_{\mathrm{total}}=E_{\mathrm{a}}+E_{\mathrm{ex}}+E_{\mathrm{s}}+E_{l}
$$

を最小にするように，台形波磁区では $\delta, d$ を，三角波磁区では $\theta_{0}, d$ を変化させた。 それぞれの最小値を比較して，最もエネル ギーの低い状態を安定磁区状態とした。

まず，計算の妥当性をチェックするため，変分法を用いて磁 化方向の分布を厳密に求めた報告例(5) 上比較した. $Q=1, t=39$ a)
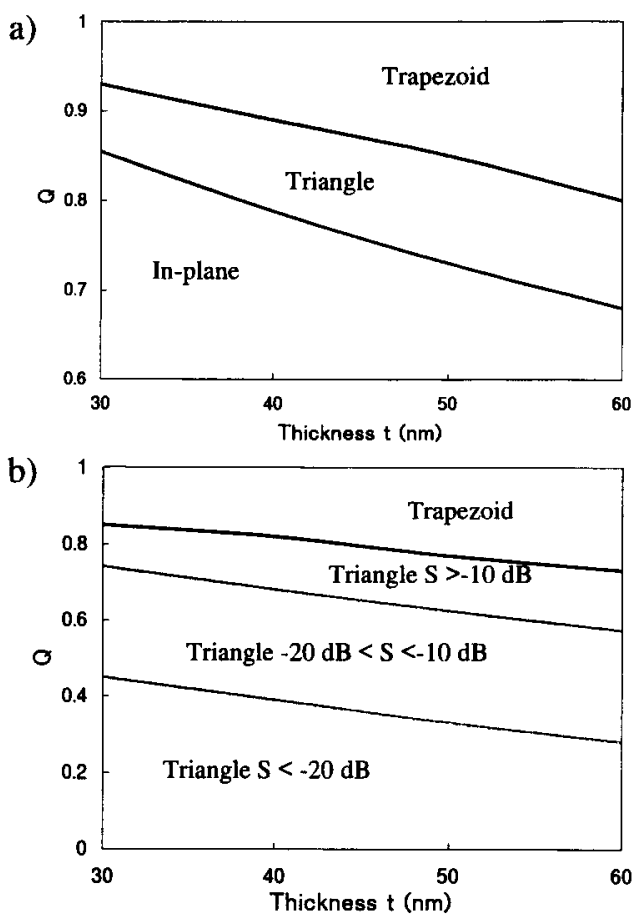

Fig. 4 Stable domain structure region calculated for (a) $H_{l}=0$, and (b) $H_{l}=100 \mathrm{Oe}$.

$\mathrm{nm}$ のときの台形波ストライプ磁区のエネルギーは $E_{\mathrm{tot}}=$ $0.902\left(2 \pi M_{\mathrm{s}}{ }^{2}\right)$ となり, 変分法による結果と $3 \%$ 以内で一致す る. 変分法では膜厚方向の $\theta$ の変化も求めているが, 用いた膜 厚では結果的に膜厚方向の变化は少なく, 用いたモデルの妥当 性が検証された。

次に求めた安定磁区状態を Fig. 4 に示した。 a) は $H_{l}=0$ の 場合で, $t=30 \mathrm{~nm}$ のとき, $Q>0.93$ では台形波ストライプ磁 区, $0.85<Q<0.93$ では三角波ストライプ磁区， $Q<0.85$ では 面内磁区が安定である，考慮した範囲では矩形波ストライプ磁 区および垂直磁区状態は現れない，膜厚が厚くなるほどストラ イプ磁区になりやすくなる，b) は $H_{l}=100 \mathrm{Oe}$ の場合であり， 常に $d=d_{\mathrm{m}}$ を保ったままエネルギーが最小となる状態を求め た結果である. $t=30 \mathrm{~nm}$ のとき，Q>0.85では台形波ストライ プ磁区，Q<0.85では三角波ストライプ磁区が安定よなり，面 内磁区状態は現れない，これは転写磁界によって三角波ス卜ラ イプ磁区のエネルギーが下がるからである。 三角波ストライプ 磁区状態はメモリ一層の情報が不完全に転写されているいわゆ る灰色マスク状態と考えることができ, 矩形波ストライプ磁区 状態で規格化したときの再生出力は次式の $S$ で与えられる.

$$
\begin{aligned}
S & =20 \log \left(\frac{2}{d} \int_{0}^{d / 2} \sin \left(\frac{2 \theta_{0} x}{d}\right) \mathrm{d} x\right) \\
& =20 \log \left[\frac{1}{\theta_{0}}\left(1-\cos \theta_{0}\right)\right]
\end{aligned}
$$

灰色マスクの目安として, $S=-10 \mathrm{~dB},-20 \mathrm{~dB}$ の境界線を Fig. $4 \mathrm{~b}$ に示してある. 対応する $\theta_{0}$ は $S=-10 \mathrm{~dB}$ に対して $\theta_{0}=37.5^{\circ},-20 \mathrm{~dB}$ に対して $\theta_{0}=11.5^{\circ}$ となる.

以後は $A=3 \times 10^{-7} \mathrm{erg} / \mathrm{cm}, M_{\mathrm{s}}=150 \mathrm{emu} / \mathrm{cm}^{3}, t=30 \mathrm{~nm}$ 


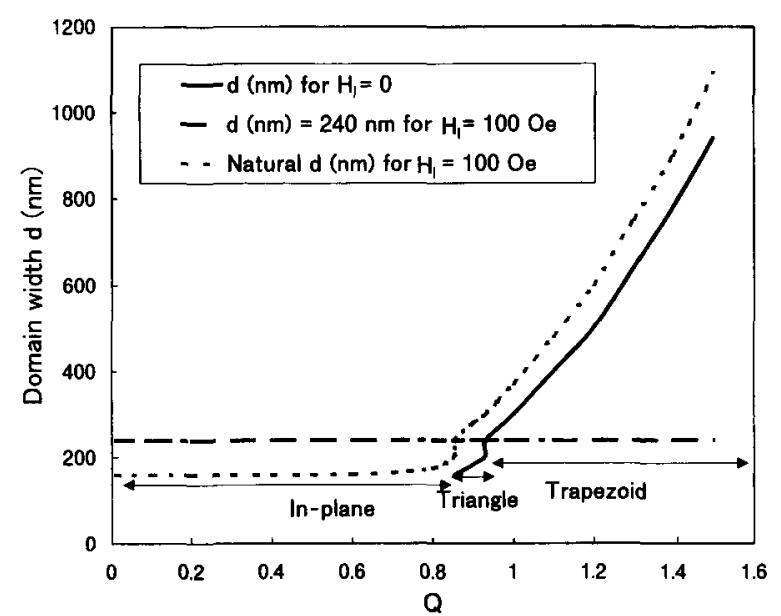

Fig. 5 Domain width $d$ as a function of $Q$ calculated for $H_{l}=0$ and $H_{l}=100 \mathrm{Oe}$.

の場合に各磁気バラメータのQ依存性を調べてみる. Fig. 5 は 磁区長 $d の Q$ 依存性を $H_{l}=0$ および $100 \mathrm{Oe} の$ 場合に対して

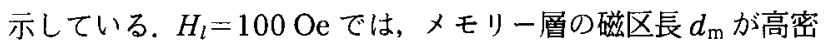
度記録の代表例である $240 \mathrm{~nm}$ に固定されている場合と，d= $d_{\mathrm{m}}$ を保って $d_{\mathrm{m}}$ を可変にした場合 (natural $d$ )を計算した. $d_{\mathrm{m}}=$ $240 \mathrm{~nm}$ の上きは再生層の $d$ も $240 \mathrm{~nm}$ となるのが安定である が, $d_{\mathrm{m}}$ が可変のときと $H_{l}=0$ のときは, 台形波ストライプ磁区 の $d$ は $Q$ が大きくなると急速に広がるのが安定である. Fig. 6 には $E_{\mathrm{tot}} /\left(2 \pi M_{\mathrm{s}}{ }^{2}\right) の Q$ 依存性を示す. $H_{l}=100 \mathrm{Oe}$, natural $d$ の場合は,メモリ一層の磁区長も $d=d_{\mathrm{m}}$ となるように都合よく 変わることを前提にしているので, エネルギーが最も低い. $H_{l}=100 \mathrm{Oe}, d_{\mathrm{m}}=240 \mathrm{~nm}$ 固定の場合は, $d=240 \mathrm{~nm}$ のきの エネルギーは可変 $d_{\mathrm{m}}$ のときより亭くなるが, $d \neq d_{\mathrm{m}}$ のとき のエネルギー $\left(H_{l}=0\right.$ のエネルギーに等しい) および垂直単磁 区状態の $E_{\text {tot }} /\left(2 \pi M_{\mathrm{s}}{ }^{2}\right)=1$ よりも小さいので, Fig. 6 の $Q>$ 0.93 では $d=d_{\mathrm{m}}$ よなる台形波ストライプ磁区が安定である.

なお， $Q>1.94$ において $d \neq d_{\mathrm{m}}$ のときのエネルギーが $d=240$ nmのときのエネルギーより低くなる.

Fig. 7 には三角波ストライプ磁区の $\theta_{0}$ の $Q$ 依存性を示して いる．台形波ストライプ磁区との境界からQが下がると $\theta_{0}$ は

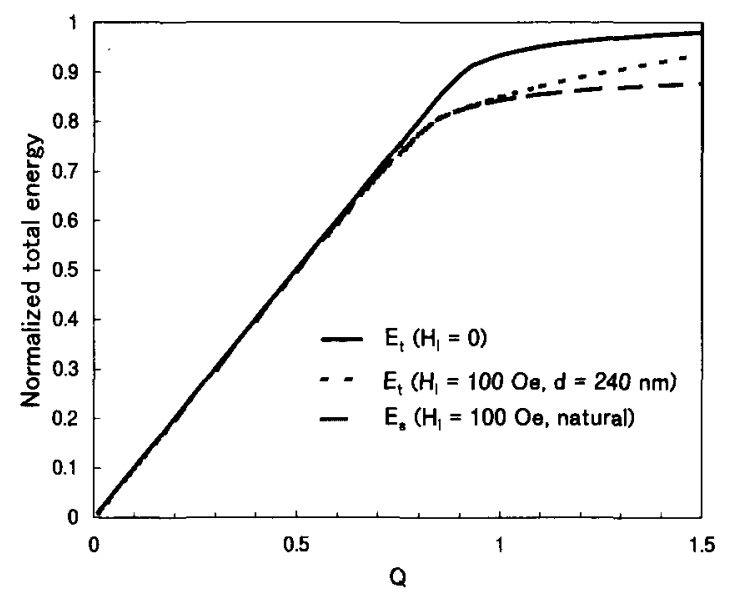

Fig. 6 Energy normalized by $2 \pi M_{\mathrm{s}}^{2}$ as a function of $Q$ calculated for $H_{l}=0$ and $H_{l}=100 \mathrm{Oe}$.

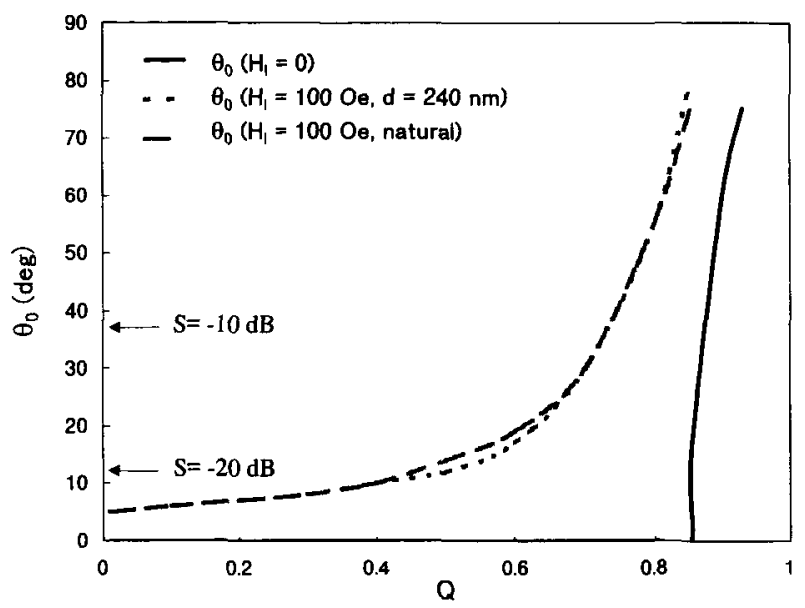

Fig. $7 \theta_{0}$ in the triangular stripe domain as a function of $Q$.

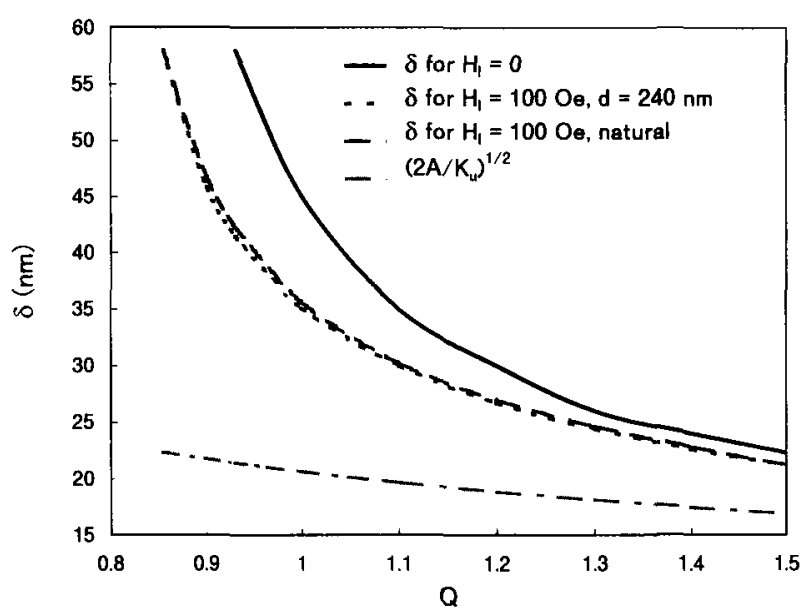

Fig. 8 Wall width parameter $d$ in the trapezoidal stripe domain as a function of $Q$.

減少するが，減少の仕方は $H_{l}=0$ のときよりも $H_{l}=100 \mathrm{Oe} の$ ときのほうが緩やかである。

Fig. 8 は磁壁幅パラメータ $\delta の Q$ 依存性を示している. 台形 波ストライプ磁区の磁壁エネルギーに関する項 $(15)+(16)$ は

$$
\delta=\sqrt{\frac{2 A}{K_{\mathrm{u}}}}
$$

のときに最小值

$$
\frac{\pi}{d} \sqrt{2 A K_{\mathrm{u}}}
$$

をとるので，Fig. 8 には(25)の値む示してある、Qが小さく なってきたときに特に， $\delta$ は (25)よりはるかに大きな值とな り, 静磁エネルギーを下げる構造をとることがわかる。

\section{5. 光スポット内の磁区構造分布}

光ディスクの再生過程においては，媒体にフォ一カスされた 光スポット内に温度分布を生じ, 磁気特性の温度依存性によっ て, 光スポット内に安定磁区構造の分布ができるはずである. 以下の手順で, 計算を行い分布を求めた.

まず線速 $4 \mathrm{~m} / \mathrm{s}$ で移動している媒体に， $\lambda=405 \mathrm{~nm}, N A=$ 0.6 の光学系で $3 \mathrm{~mW}$ のレーザを照射したときの温度分布を計 


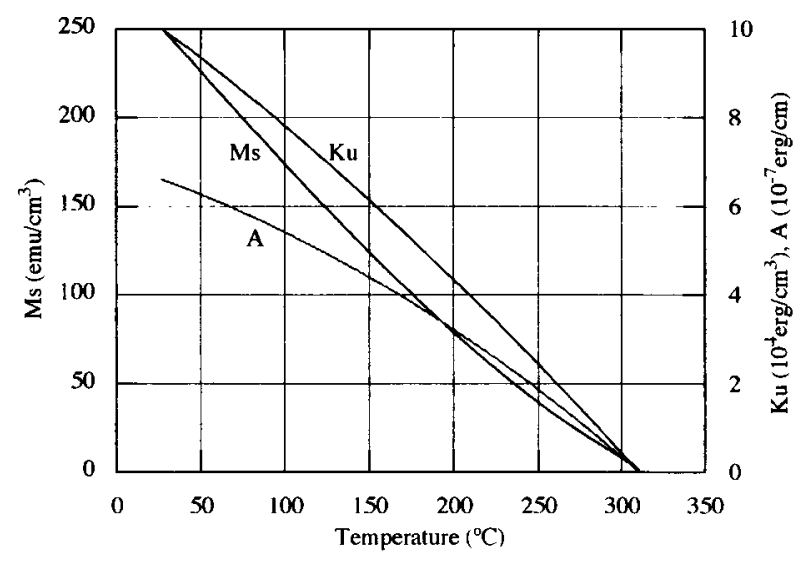

Fig. 9 Temperature dependence of $A, K_{\mathrm{u}}$, and $M_{\mathrm{s}}$ obtained by using molecular field theory.

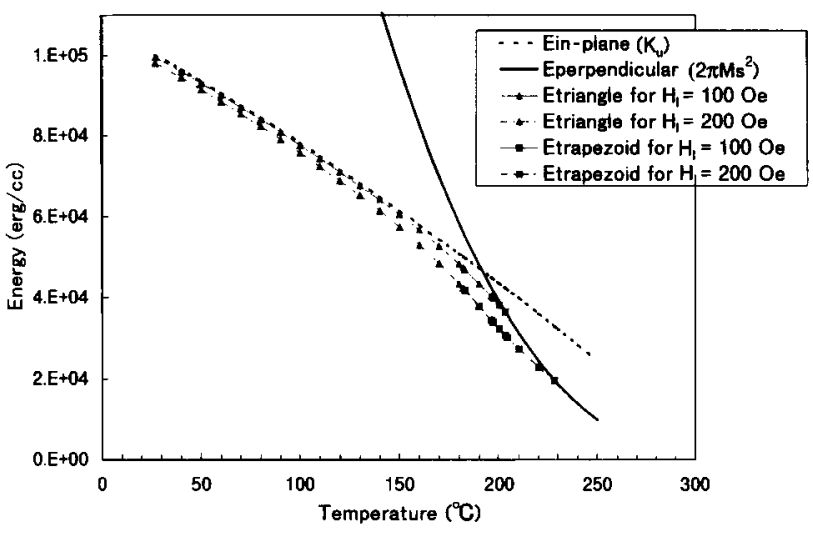

Fig. 10 Temperature dependence of the total energy calculated for the stable domain state.

算した ${ }^{6)}$. 次に再生層の室温での $M_{\mathrm{s}}, K_{\mathrm{u}}$ 上キュリー温度の実験 值を用いて，分子場近似にて $A, K_{\mathrm{u}}, M_{\mathrm{s}}$ の温度依存性を Fig. 9 のように求めた. 分子場の計算は, 疑似二元系で行った ${ }^{71.8 !}$. 計 算パラメータは, $\mathrm{Gd} の$ 磁気モーメントを $7 \mu_{\mathrm{B}}, \mathrm{Fe}-\mathrm{Co} の$ 平均 の磁気モーメントを $1.98 \mu_{\mathrm{B}}, \mathrm{Gd} と \mathrm{Gd}$ の間の交換積分を $5.0 \times$ $10^{-16} \mathrm{erg}, \mathrm{Gd} と \mathrm{Fe}-\mathrm{Co}$ の間の交換積分を $-1.5 \times 10^{-15} \mathrm{erg}$, $\mathrm{Fe}-\mathrm{Co}$ と $\mathrm{Fe}-\mathrm{Co}$ の間の交換積分を $6.07 \times 10^{-15} \mathrm{erg}$ とした。 異方性係数は, $7.12 \times 10^{-20} \mathrm{erg}$ とした。

各温度における安定な磁区状態は前章までの手法で計算する ことができる，各温度における $K_{\mathrm{u}}, 2 \pi M_{\mathrm{s}}{ }^{2}$ ，および最も安定な ストライプ磁区のエネルギーを Fig. 10 に示す. 結果は $d=$ $240 \mathrm{~nm}$ に固定したメモリ一層から $H_{l}=100$ Oe の転写磁界を 受けているときは $204^{\circ} \mathrm{C} \leqq T$ では垂直磁化状態が， $197^{\circ} \mathrm{C} \leqq T$ $\leqq 203^{\circ} \mathrm{C}$ では台形波ストライブ磁区が， $T \leqq 196^{\circ} \mathrm{C}$ では三角波 ストライプ磁区がそれぞれ安定である。三角波磁区で $S=-10$ $\mathrm{dB}$ となるのは $170^{\circ} \mathrm{C},-20 \mathrm{~dB}$ となるのは $123^{\circ} \mathrm{C}$ である. 同様 に $H_{l}=200$ Oe の上きは, $229^{\circ} \mathrm{C} \leqq T$ では垂直磁化状態が, $183^{\circ} \mathrm{C} \leqq T \leqq 228^{\circ} \mathrm{C}$ では台形波ストライプ磁区が， $T \leqq 182^{\circ} \mathrm{C}$ で は三角波ストライプ磁区がそれぞれ安定である．三角波磁区で $S=-10 \mathrm{~dB}$ となるのは $149^{\circ} \mathrm{C},-20 \mathrm{~dB}$ となるのは $59^{\circ} \mathrm{C}$ であ る.

最後に光スポット内の温度に対応する安定磁区状態の分布を 計算した. $H_{l}=100,200$ Oe の結果をそれぞれ Fig. 11, 12 に示

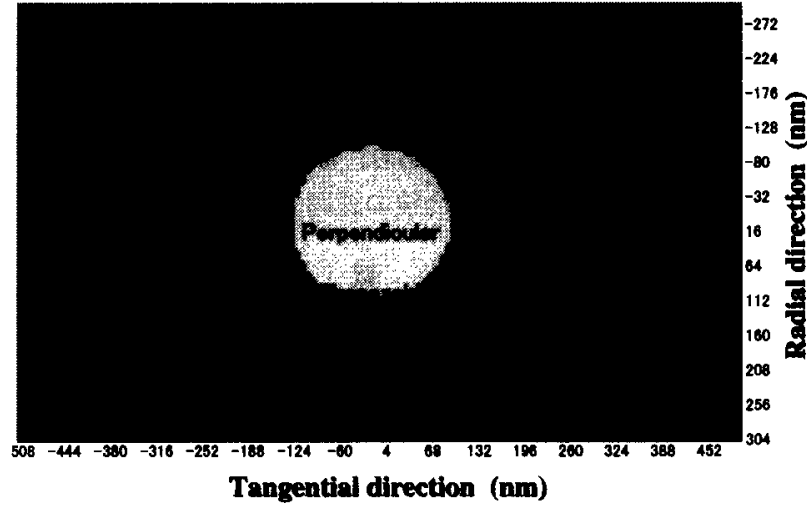

Fig. 11 Region of the stable domain state in the optical spot for $H_{l}=100 \mathrm{Oe}$.

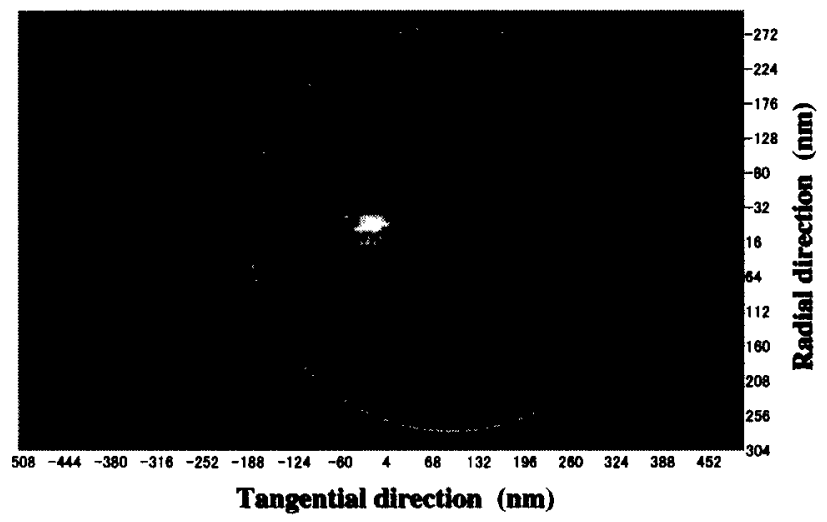

Fig. 12 Region of stable domain state in the optical spot for $H_{l}=200 \mathrm{Oe}$.

す. 白い円は $1 / e^{2}$ 強度の光スポットを表し, 濃度の異なる領域 の境界線は Fig. 10 で示した臨界温度の等温線になっている. $H_{l}=100 \mathrm{Oe}$ の場合は光スポットの中央部に垂直磁化領域がで きる.これはメモリー層の磁区の向きにかかわらず，一方向を 向くのが安定なことを意味するので，転写が不安定になること を示唆している. 一方, $H_{l}=200 \mathrm{Oe}$ の場合には, 光スポット中 央部に台形波ストライプ磁区の安定領域ができて, 良好な転写 特性が期待されるが，その周りにS> $-20 \mathrm{~dB}$ の角波ストラ イプ磁区が光スポット全面に拡がっているので, いわゆる灰色 マスク状態となっており，クロストーク特性の悪化が縠念され る.このように, メモリー層からの転写特性とアパーチャーの 周りのマスク特性のバランスを考慮した膜設計が重要であるこ とがわかる。

\section{6. 結 び}

$\mathrm{CAD}$ メ゙ィアの再生層のように, 小さな垂直磁気異方性を もつ薄膜の磁区構造を, ストライプ磁区のモデル化により計算 した。メモリ一層からの転写磁界がないときは，三角波ストラ イプ磁区は限定された条件でしか実現されないが, 100 Oe 程 度の転写磁界があると, 広い範囲で安定になる。

光スポット内の安定磁区分布を再生パワーによる温度分布 之, 磁気特性の温度依存性よりシミュレートした。計算した静 磁結合磁性 2 層膜の例では, 転写特性とマスク特性の両立が難 しいという結果になったが, これは再生層と非磁性層の間に再 
生補助層またはマスク層と呼ばれる層を挿入することで, 解像 度を改善するような手法"'が有効であることを示唆していると 屯言える.いずれにしても，本論文で示した計算手法は超解像 動作と関連づけることが可能であり，膜設計に有用と考えられ る. 磁性 3 層膜の取り扱いは今後の課題である.

\section{文献}

1) Y. Murakami, N. Iketani, J. Nakajima, A. Takahashi, K. Ohta, and T. Ishikawa: J. Magn. Soc. Jpn., 17 (Suppl. No. S1), 201 (1993).

2）桜井良文編集：磁性薄膜工学, p. 103 (丸善, 東京, 1977).
3) N. Saito, H. Fujiwara, and Y. Sugita:J. Phys. Soc. Jpn., 19, 1116 (1964).

4) 近角㭵信：強磁性体の物理 (下), p. 193 (裳華房, 東京, 1984)

5) Y.-O. Tu: J. Appl. Phys., 52, 3130 (1981).

6) O.W. Shih: J. Appl. Phys., 75, 4382 (1994)

7) 田㚼正浩：重希土類-3d 遷移金属合金交換結合多層膜の熱磁気特 性および磁気光学特性に関する研究（博士論文, 三重大学, 1998), pp. 26-33.

8) M. Mansuripur and M. F. Ruane: IEEE Trans. Magn., 22, 33 (1986).

9) 広兼順司, 高橋 明: 日本応用磁気学会誌, 21, 1076 (1997), 2001 年 1 月 31 日受理, 2001 年 4 月 17 日採録 